\title{
Perception of elderly related to the risk of falls and their associated factors
}

\author{
Percepção de idosos relacionada ao risco de quedas e seus fatores associados \\ Percepción de adultos mayores relacionada con el riesgo de caídas y sus factores asociados
}

\author{
Bruna Soares Vasques Blaz ${ }^{1}(10)$ \\ Rosemeiry Capriata de Souza Azevedo ${ }^{2}$ \\ Daniela Luzia Zagoto Agulhó ${ }^{2}$ (B) \\ Annelita Almeida Oliveira Reiners ${ }^{2}$ (C) \\ Neuber José Segri ${ }^{3}$ (D) \\ Tiago Antônio Borges Pinheiro ${ }^{4}$
}

1. Prefeitura Municipal de Barra do Bugres. Barra do Bugres, MT, Brasil.

2. Universidade Federal de Mato Grosso, Departamento de Enfermagem. Cuiabá, MT, Brasil. 3. Universidade Federal de Mato Grosso, Faculdade de Estatística. Cuiabá, MT, Brasil.

4. Universidade Federal de Mato Grosso, Faculdade de Medicina. Cuiabá, MT, Brasil.
Corresponding author Bruna Soares Vasques Blaz E-mail: brunablaz@hotmail.com

Submitted on 03/08/2019. Accepted on 09/18/2019.

\section{Abstract}

Objective: To analyze the association of the perception of the elderly on the risk factors for falls. Methods: An Analytical crosssectional study with 190 elderly from the Healthy Longevity Program of a public university in Mato Grosso, from May to August 2016. The collection wasdone through a structured interview and vignettes. Performed descriptive and bivariate analyzes - Pearson chi-square test $\left(\mathrm{x}^{2}\right)$ significance level of $5 \%$. The crude and adjusted prevalence ratios (PR), with confidence intervals (95\%), were also estimated, followed by Poisson multiple regression. Results: Of the participants, $64.2 \%$ had a satisfactory perception about the risk factors for falls. The prevalence of unsatisfactory risk perception was $105 \%$ higher in those with income from 1 to 3 minimum wages, $75 \%$ higher in those with low risk of falls and $46 \%$ higher in those who did not attend another social group. Conclusion and implications for the practice: A significant proportion of the elderly have an unsatisfactory risk perception for the risk factors for falls associated with low income, not attending another social group and the low risk of falls. Knowledge about the risk perception of falls in the elderly helps nurses to plan and implement fall prevention programs for this population.

Keywords: Risk factors; Falls; Aged.

\section{Resumo}

Objetivo: Analisar a associação da percepção de idosos sobre os fatores de risco de ocorrência de quedas. Método: Estudo transversal analítico com 190 idosos do Programa Longevidade Saudável, de uma universidade pública de Mato Grosso, no período de maio a agosto de 2016. A coleta ocorreu por entrevista estruturada e vinhetas. Realizaram-se análises descritiva e bivariada - teste de qui-quadrado de Pearson $\left(\mathrm{x}^{2}\right)$ nível de significância de $5 \%$. Também foram estimadas as razões de prevalências (RP) brutas e ajustadas, com intervalos de confiança (95\%), seguidas pela regressão múltipla de Poisson. Resultados: Dentre os participantes, $64,2 \%$ apresentaram percepção satisfatória sobre os fatores de risco referentes a quedas. A prevalência de percepção de risco insatisfatória foi $105 \%$ maior naqueles com renda de 1 a 3 salários mínimos, $75 \%$ maior nos de baixo risco de quedas e $46 \%$ maior naqueles que não frequentam outro grupo social. Conclusão e Implicações para a prática: Parcela significativa de idosos possui percepção de risco insatisfatória para os fatores de risco de quedas associada a baixa renda, não frequentar outro grupo social e ao baixo risco de queda. O conhecimento sobre a percepção de risco de quedas dos idosos auxilia os enfermeiros no planejamento e implementação de programas de prevenção de quedas dessa população.

Palavras-chave: Fatores de risco; Quedas; Idoso.

\section{Resumen}

Objetivo: Analizar la asociación de la percepción de adultos mayores sobre los factores de riesgo para caídas. Métodos: Estudio analítico transversal con 190 participantes del Programa de Longevidad Saludable de una universidad pública en Mato Grosso realizado entre mayo y agosto de 2016. Recolección realizada por entrevista estructurada y viñetas. Análisis descriptivo y bivariado - prueba chi-cuadrado de Pearson $\left(x^{2}\right)$ con nivel de significancia del 5\%. También fueron estimadas razones de prevalencias (RP) brutas y ajustadas, con intervalos de confianza (95\%), seguidas por la regresión múltiple de Poisson. Resultados: El $64,2 \%$ presentaron percepción satisfactoria sobre los factores de riesgo para caídas. La prevalencia de percepción de riesgo insatisfactoria fue un $105 \%$ mayor en aquellos con ingresos de 1 a 3 salarios mínimos, un $75 \%$ mayor en los de bajo riesgo y un $46 \%$ mayor en aquellos que no frecuentan otro grupo social. Conclusión e Implicaciones para la práctica: Proporción significativa de personas mayores tiene percepción insatisfactoria para los factores asociados a los bajos ingresos, no frecuentar otro grupo social y el bajo riesgo de caída. Tener conocimiento sobre la percepción de los mayores auxilia a los enfermeros en la planificación e implementación de programas de prevención de caídas de esa población.

Palabras claves: Factores de riesgo; Caídas; Anciano. 


\section{INTRODUCTION}

Approximately $28 \%$ to $35 \%$ of people around the world older than 65 years old fall every year and figures are even higher among those older than 70 years of age, from $32 \%$ to $42 \%{ }^{1}$. One study conducted in 70 cities located in different regions of Brazil reports a prevalence of falls of $25.1 \%$. Of these, $1.8 \%$ resulted in hip or femur fractures and, among them, $31.8 \%$ required surgery with prosthetic replacement ${ }^{2}$.

The factors contributing to falls among these individuals are well known and are related to the aging process (intrinsic factors), along with domestic and public physical environments (extrinsic factors) and the elderly individuals' behaviors ${ }^{1}$. Behaviors result from decisions people make when facing a risk situation ${ }^{1}$, which depend on the individual's perception of risk factors for falls.

Risk perception (RP) is how an individual interprets risks based on a set of beliefs, values, and life experiences, which gives meaning to each harmful event, as well as understanding of specific threats. Risk perception works as an organizing axis that guides decisions and behaviors before, during and after a risk situation ${ }^{3}$, though it may be altered among individuals with cognitive deficit ${ }^{3}$.

Studies show that falls among elderly individuals can be prevented if individuals, as well as health workers, family members and caregivers adopt certain measures, such as improving lighting, removing rugs around the home, using appropriate shoes, among other actions ${ }^{3-5}$. These measures, however, may not be effective if elderly individuals lack an appropriate perception of the presence of risk factors for falls in their daily activities.

Studies addressing RP have been conducted, especially in the fields of psychology, the agrarian sciences, economics, education, nutrition, and architecture, among others ${ }^{6-9}$. Studies in the health field have focused on communicable diseases such as HIV and hepatitis, occupational risks, cancer (breast, ovarian, lung), osteoporosis, and public health ${ }^{10-12}$.

Thus, little is known about the perceptions of elderly individuals regarding risks. Studies ${ }^{13-16}$ show that these individuals are able to perceive risk factors. Despite available evidence, however, authors conclude that further studies addressing RP are needed to confirm results among other groups of elderly individuals and acquire new information regarding associated factors. This study's objective was to analyze associations of the perceptions of elderly individuals regarding risk factors for falls.

\section{METHOD}

Cross-sectional and analytical study conducted with individuals 60 years old or older, participating in the Healthy Longevity Program of a public university located in the state of Mato Grosso, Brazil. The program provides physical, cultural and educational activities to promote the health of elderly individuals.

All 306 elderly individuals enrolled in the program in 2016 were invited to participate. Of these, 20 refused, 83 left the program, and 13 did not meet the inclusion criteria - presenting cognitive capacity according to the Mini Mental State Exam (MMSE) $)^{17}$ and establishing communication with the researcher in order to check understanding of questions. The final sample was 190 elderly individuals.

Data were collected from May to August 2016 after free and informed consent forms were signed. Sociodemographic data and the health conditions of the elderly individuals were obtained through an interview based on a questionnaire, conducted by the researcher and other previously trained assistants.

The perceptions of the elderly individuals regarding risk factors for falls were verified using vignettes, a technique that consists of a brief description of an event, fictitious or real, using narrations, images or videos ${ }^{18}$. The vignettes were developed according to three stages: (1) format and content were selected; (2) an instrument was developed to collect data based on the vignettes; and (3) the content of the vignettes was validated by judges.

Twelve vignettes portraying images of situations elderly individuals experience in their routines were used. Each situation presented various environmental and behavioral risk factors for falls (1 to 5 risk factors) (Chart 1). The vignettes were presented using a 10" portable computer.

This study's dependent variable was the perception of elderly individuals concerning risk factors for falls (elderly individuals RP), which was verified with the question: Is there a possibility for an elderly individual to fall in this situation/ environment? In the absence of a reference to classify of RP of the elderly, we opted for an arbitrary classification. Since the vignettes presented various risk factors, we considered the individual had a satisfactory $\mathrm{RP}$ if $\mathrm{s} /$ he identified at least one risk factor in each vignette (totalizing 12) and unsatisfactory RP if s/ he identified none or up to 11 risk factors for falls.

The independent variables include sociodemographic data and health conditions. The following sociodemographic information was addressed: sex (male/female); age (60 to 69 years old/70 to 79 years old/80 years old or older); marital status (single/married or in a consensual union/separated or divorced/ widowed); years of schooling (illiterate/ 1 to 4 years $/ 5$ to 8 years $/ 9$ to 10 years/>11 years); occupational situation (employed/retired/ retired but still working/unemployed); income (none/up to one times the minimum wage (MW)/from 2 to 3 times the $\mathrm{MW} /$ more than 3 times the MW); family arrangement (living alone/with spouse or partner/family member/spouse and a family member/ non-family caregiver/other people); participate in a social group other than the HLP (yes/no); visits friends or relatives (yes/no); and receives visits (yes/no).

The variables related to health conditions include selfperceived health (very poor, poor, regular, good, very good); smoker (yes/no/former smoker); alcohol consumption (yes/no/ sometimes); health problems (yes/no, if yes, how many? Which one(s); medications (yes/no); self-reported change of balance (yes/no); self-reported mobility difficulties (yes/no); exercises (yes/no). Degree of dependence for daily living activities (DLA) 
Chart 1. Description of risk factors included in each vignette presented to the elderly individuals attending the Healthy Longevity Program. Cuiabá, MT, Brazil - 2016.

\begin{tabular}{|llcc|}
\hline \multirow{2}{*}{ Vignettes } & \multicolumn{1}{c}{ Risk factors for falls } & $\begin{array}{c}\text { Number of } \\
\text { RF per vig- } \\
\text { nette }\end{array}$ & $\begin{array}{c}\text { Minimum num- } \\
\text { ber of perceived } \\
\text { risk factors }\end{array}$ \\
\hline 01 & Sofa foot, rug, slick floor. & 03 & 02 \\
02 & Steps, not using handrail, carrying weight when climbing a stair & 03 & 02 \\
03 & Uneven sidewalk & 01 & 01 \\
04 & Inappropriate slippers, slick floor & 02 & 01 \\
05 & Objects scattered on the floor, rug & 02 & 01 \\
06 & Climbing a stair without a safety device & 02 & 01 \\
07 & Slick floor, climbing on a bench, using inappropriate slippers & 03 & 02 \\
08 & Toys scattered on the floor, children around, rug & 03 & 02 \\
\hline 09 & Wet and uneven floor, a hose, washing the sidewalk wearing inappropriate & 05 & 03 \\
\hline 10 & slippers. & 05 & 03 \\
11 & Vases on stairs, inappropriate lighting, misuse of cane, rug on stairs, steps & 03 & 02 \\
\hline 12 & Climbing the steps of a bus, uneven sidewalk, carrying weight when climbing & 03 & 01 \\
\hline Total & steps & 01 & $\mathbf{2 1}$ \\
\hline
\end{tabular}

Source: Developed by the researcher, 2016.

was also assessed using the Katz Index ${ }^{17}$ and Lawton and Brody's Lawton Instrumental Activities of Daily Living Scale. ${ }^{17}$

Risk for falls was assessed using the Falls Risk Score ${ }^{19}$ and history of falls was verified through the following questions: any fall in the last 12 months? (yes/no, if yes, how many?); consequences of falls(s)? (abrasions/bruises/fractures/sprains). Fear of falling was assessed using Falls Efficacy Scale International-FES-I 20

Data were coded and double-entered into spreadsheets in Epi-Info, version 3.2.5. Descriptive analysis was performed using relative and absolute frequency. Pearson's Chi-square test was used in the bivariate analysis with significance level set at $5 \%$ to identify associations between the dependent variable and independent variables. Prevalence, raw and adjusted prevalence ratios (PR) were estimated, as were the respective confidence intervals $(95 \%)$ regarding the perceptions of elderly individuals of environmental and behavioral risk factors for falls. Afterwards, Poisson's multiple regression was performed with robust variance using the stepwise forward method. Only the variables presenting $p<0.20$ in the bivariate analysis were considered in the final multiple model, adjusted for sex, age and sensorial problems.

The study was approved by the Institutional Review Board at the Júlio Muller University Hospital (Opinion report 1.375.300/2015).

\section{RESULTS}

Most elderly individuals were women (90.5\%), aged between 60 and 69 years old $(67.3 \%)$, had more than 11 years of schooling $(58.9 \%)$ and a large share of the individuals were married (36.2\%).
In terms of occupational situation, most (51.5\%) were retired and $36.9 \%$ had a monthly income from 2 to 3 times the minimum wage. More than half $(57.4 \%)$ take part in a social group other than the HLP; $91.1 \%$ have the habit of visiting friends and relatives and also receive visits $(93.7 \%)$.

Table 1 presents the health conditions of the elderly participants.

In regard to the prevalence of the perception of the elderly individuals regarding environmental and behavioral risk factors for falls, most (64.2\%) presented satisfactory RP.

Considering the prevalence of unsatisfactory RP of the elderly in relation to the risk factors for falls in this study, the bivariate analysis between unsatisfactory RP and sociodemographic variables revealed a significant association with the variables: years of schooling $(p<0.001)$, occupational situation $(p=0.048)$ and monthly income $(p=0.004)$ (Table 3). Notes:

A significant association between unsatisfactory RP of the elderly and risk for falls $(p=0.022$ ) was found, while no statistically significant association was found between unsatisfactory RP and health conditions.

Regardless of the risk for falls, whether the individual participates in another social group or not, his/her sex or age, or whether the individual reports sensorial problems or not, the final multiple model shows that the prevalence of RP unsatisfactory was $105 \%$ greater among those with an income from 1 to 3 times the minimum wage than among those with higher incomes ( 3 or more times the MW) (Table 3).

The prevalence of RP unsatisfactory was $75 \%$ greater among individuals with a low risk for falls, compared to those at a high 
Table 1. Distribution of elderly individuals participating in the Healthy Longevity Program at the UFMT, according to health conditions. Cuiabá, MT, Brazil - 2016.

\begin{tabular}{|c|c|c|}
\hline Variables & Frequency (n) & Percentage (\%) \\
\hline \multicolumn{3}{|l|}{ Health self-assessment* } \\
\hline Poor & 5 & 2.6 \\
\hline Regular & 60 & 31.6 \\
\hline Good & 93 & 49.0 \\
\hline Very good & 32 & 16.8 \\
\hline \multicolumn{3}{|l|}{ Smoker } \\
\hline Yes & 3 & 1.6 \\
\hline No & 150 & 78.9 \\
\hline Former smoker & 37 & 19.5 \\
\hline \multicolumn{3}{|l|}{ Consumes alcohol } \\
\hline Yes & 6 & 3.2 \\
\hline Sometimes & 59 & 31.1 \\
\hline No & 125 & 65.8 \\
\hline \multicolumn{3}{|l|}{ Health Problems } \\
\hline Yes & 187 & 98.4 \\
\hline No & 3 & 1.6 \\
\hline \multicolumn{3}{|l|}{ Number of health problems** } \\
\hline One health problem & 20 & 10.7 \\
\hline Two health problems & 46 & 24.6 \\
\hline More than two health problems & 121 & 64.7 \\
\hline \multicolumn{3}{|l|}{ Self-reported health problems*** } \\
\hline Sensorial $^{1}$ & 166 & 88.8 \\
\hline Hypertension & 118 & 63.1 \\
\hline Osteoarticular ${ }^{2}$ & 68 & 36.4 \\
\hline Back problems & 41 & 21.9 \\
\hline Degenerative diseases ${ }^{3}$ & 2 & 1.1 \\
\hline Dyslipidemia & 51 & 27.3 \\
\hline Diabetes & 25 & 27.3 \\
\hline $\mathrm{CHF}$ & 2 & 1.1 \\
\hline Urinary incontinence & 41 & 21.6 \\
\hline Others & 84 & 44.2 \\
\hline \multicolumn{3}{|l|}{ Uses medication } \\
\hline Yes & 171 & 90.0 \\
\hline No & 19 & 10.0 \\
\hline \multicolumn{3}{|l|}{ Self-reported balance status } \\
\hline Yes & 45 & 23.7 \\
\hline No & 145 & 76.3 \\
\hline \multicolumn{3}{|l|}{ Self-reported difficult mobility } \\
\hline Yes & 22 & 11.6 \\
\hline No & 168 & 88.4 \\
\hline \multicolumn{3}{|l|}{ Exercises } \\
\hline Yes & 182 & 95.8 \\
\hline No & 8 & 4.2 \\
\hline \multicolumn{3}{|c|}{ Level of dependence for DLA and IDLA**** } \\
\hline Independent & 190 & 100.0 \\
\hline Dependent & 0 & 0.0 \\
\hline
\end{tabular}

Notes: *Classification according to VIGITEL (2014). ${ }^{* *} \mathrm{n}=187$ (refers to individuals with health problems). ${ }^{* * *}$ Multiple choice questions 1 Sensorial: eyesight, hearing, tactile or smell; 2 Osteoarticular conditions: arthritis, arthrosis, osteoporosis or rheumatism; 3 Degenerative diseases: Alzheimer or Parkinson. ****Among all the elderly individuals, $n=41$ (presented urinary incontinence) and, in regard to DLA, were considered independent for all activities but one (had occasional "accidents" - urine or feces loss) but were considered totally independent regardless. 
Table 2. Distribution of elderly individuals participating in the Healthy Longevity Program at the UFMT according to history of falls, risk for falls, and fear of falling. Cuiabá, MT, Brazil - 2016.

\begin{tabular}{|c|c|c|}
\hline Variables & Frequency $(n)$ & Percentage (\%) \\
\hline \multicolumn{3}{|c|}{ Self-reported falls in the last $\mathbf{1 2}$ months } \\
\hline Yes & 41 & 21.6 \\
\hline No & 149 & 78.4 \\
\hline \multicolumn{3}{|l|}{ Numbers of self-reported falls } \\
\hline One fall & 21 & 51.3 \\
\hline Two falls & 14 & 34.1 \\
\hline More than two falls & 6 & 14.6 \\
\hline \multicolumn{3}{|c|}{ Self-reported consequences from fall** } \\
\hline & 16 & 38.9 \\
\hline Bruise & 14 & 34.1 \\
\hline Fracture & 5 & 12.2 \\
\hline Sprains & 4 & 9.8 \\
\hline \multicolumn{3}{|l|}{ Risk for falls (Fall Risk Score) } \\
\hline Low risk for falls & 99 & 52.1 \\
\hline High risk for falls & 91 & 47.9 \\
\hline \multicolumn{3}{|l|}{ Fear of falling (FES-I-BRAZIL) } \\
\hline Little worried about falling & 113 & 59.5 \\
\hline Very worried about falling & 54 & 28.4 \\
\hline Extremely worried about falling & 23 & 12.1 \\
\hline
\end{tabular}

risk for falls and $46 \%$ greater among those who do not participate in a social group other than the HLP, regardless of the remaining associated variables, such as sex, age, or whether the individual reported sensorial problems. A goodness-of-fit test was performed and showed the model is appropriate $(p=0.1972)$ (Table 4$)$.

\section{DISCUSSION}

Because this study addressed elderly individuals composing a specific group, and considering that RP is a subjective variable, susceptible to different conceptions of risk for falls, these results cannot be generalized. The findings, however, expand knowledge about one of the aspects that influence the frequency of falls among elderly individuals and how to prevent them.

The higher frequency of satisfactory RP identified in this study reinforce results reported by other studies ${ }^{13-16}$ showing that elderly individuals are generally aware of risks for falls. It may be considered a good result because it suggests there is greater possibility of preventing falls among elderly individuals.

The frequency of unsatisfactory RP, however, is of concern and has important implications. The lower the level of an individual's risk perception, the more likely s/he is to come to harm ${ }^{21}$, that is, these individuals are more likely to expose themselves to risks as they fail to perceive them.

The participants' unsatisfactory RP is possibly explained by the way they assessed the risks presented in the vignettes. Some authors argue that the conception of risk is inherently subjective; that is, risk's interpretation depends on how each individual, in his/her judgment process, analyzes and considers various elements, such as one's experience, knowledge, potential harm, meanings, and values, among others ${ }^{22-23}$. RP is directly linked to the way people think, represent, classify or analyze the various forms of threats (risks) to which they are exposed or of which they are aware ${ }^{22}$.

In this sense, it may be that the RP of the individuals addressed in this study in regard to the risk factors presented in the vignettes was influenced by individual characteristics. That is, these individuals were young, independent, self-assessed their health as good, had a history of few falls, and were not very concerned over falls. Elderly individuals with these characteristics are less likely to perceive risk factors for falls as being a risk for them, as they do not identify themselves as being at a greater risk to fall. One study conducted in Australia reports that the individuals identified themselves as "someone who does not fall", a strategy to protect themselves from being viewed as physical incompetents ${ }^{24}$.

The association found in this study between unsatisfactory $\mathrm{RP}$ and low income seems to be coherent, as income is a determinant factor in peoples' living and health conditions. One study shows that low income hinders one's access to health services and influences one's level of information ${ }^{25}$.

Inadequate knowledge or the lack of knowledge coupled with an unfavorable financial situation generally leads people to expose themselves more frequently to risk situations ${ }^{26}$. One study conducted in Rio Grande do Sul, Brazil shows that people with lower income less frequently perceived risks compared to 
Table 3. Prevalence of the perceptions of elderly individuals participating in the Healthy Longevity Program at the UFMT regarding environmental and behavioral risk factors for falls, according to sociodemographic variables Cuiabá, MT, Brazil - 2016

\begin{tabular}{|c|c|c|c|}
\hline Variables & n* & Prevalence (\%) & $p$-value** \\
\hline Female & 63 & 36.6 & \multirow{2}{*}{0.456} \\
\hline Male & 5 & 27.8 & \\
\hline \multicolumn{4}{|l|}{ Age group } \\
\hline $60-69$ years old & 47 & 36.7 & \multirow{3}{*}{0.196} \\
\hline $70-79$ years old & 17 & 30.4 & \\
\hline 80 years old or older & 4 & 66.7 & \\
\hline \multicolumn{4}{|l|}{ Marital status } \\
\hline Single & 5 & 23.8 & \multirow{4}{*}{0.060} \\
\hline Married or stable union & 21 & 30.4 & \\
\hline Separated or divorced & 14 & 31.8 & \\
\hline Widowed & 28 & 50.0 & \\
\hline \multicolumn{4}{|l|}{ Years of schooling } \\
\hline 1 to 4 years & 22 & 64.7 & \multirow{4}{*}{$<0.001$} \\
\hline 5 to 8 years & 14 & 41.2 & \\
\hline 9 to 10 years & 7 & 70.0 & \\
\hline$>11$ years & 25 & 22.3 & \\
\hline \multicolumn{4}{|l|}{ Occupational situation } \\
\hline Retired & 31 & 31.6 & \multirow{7}{*}{0.048} \\
\hline Working & 6 & 42.9 & \\
\hline Retired but still working & 1 & 6.7 & \\
\hline Pensioner & 14 & 56.0 & \\
\hline Retired and pensioner & 8 & 50.0 & \\
\hline Pensioner and working & 2 & 28.6 & \\
\hline Unemployed & 6 & 40.0 & \\
\hline \multicolumn{4}{|l|}{ Monthly income } \\
\hline One to 3 times the minimum wage & 55 & 42.4 & \multirow{2}{*}{0.004} \\
\hline More than 3 times the minimum wage & 13 & 21.3 & \\
\hline \multicolumn{4}{|l|}{ Family arrangement } \\
\hline Living alone & 16 & 32.7 & \multirow{4}{*}{0.489} \\
\hline Spouse or partner & 9 & 29.0 & \\
\hline Family (Spouse + family member) & 12 & 32.4 & \\
\hline Family (Only family members, no spouse/partner) & 31 & 42.5 & \\
\hline \multicolumn{4}{|l|}{ Visits friends/relatives } \\
\hline Yes & 33 & 30.3 & \multirow{2}{*}{0.066} \\
\hline No & 35 & 43.2 & \\
\hline \multicolumn{4}{|l|}{ Visits friends/relatives } \\
\hline Yes & 61 & 35.3 & \multirow{2}{*}{0.627} \\
\hline No & 7 & 41.2 & \\
\hline \multicolumn{4}{|l|}{ Receives visits from friends/relatives } \\
\hline Yes & 63 & 35.4 & \multirow{2}{*}{0.661} \\
\hline No & 5 & 41.7 & \\
\hline
\end{tabular}

Notes: $\mathrm{n}=68$ - refer to all elderly individuals with unsatisfactory RP of risk factor for falls; ${ }^{* *}$ Chi-square test. 
Table 4. Poisson's Multiple Regression Model: variables associated with unsatisfactory perception of environmental and behavioral risk factors for falls among individuals in the Healthy Longevity Program at UFMT. Cuiabá, MT, Brazil $-2016$.

\begin{tabular}{|c|c|c|c|c|}
\hline Variables & Prevalence (\%) & Raw PR (IC95\%) & Adjusted PR* (IC95\%) & $p$-value \\
\hline \multicolumn{5}{|l|}{ Income } \\
\hline One to 3 times the minimum wage & 42.4 & $2.00(1.19-3.38)$ & $2.05(1.23-3.41)$ & 0.006 \\
\hline \multicolumn{5}{|l|}{ Risk for falls } \\
\hline Low risk for falls & 43.4 & $1.58(1.06-2.37)$ & $1.75(1.16-2.66)$ & 0.008 \\
\hline \multicolumn{5}{|l|}{ Participates in other social group(s) } \\
\hline Yes & 30.3 & 1.00 & 1.00 & \multirow{2}{*}{0.042} \\
\hline No & 43.2 & $1.43(0.98-2.09)$ & $1.46(1.01-2.11)$ & \\
\hline
\end{tabular}

Notes: *Adjusted for sex, age and sensorial problems; PR: prevalence ratio; $\mathrm{Cl} 95 \%$ : confidence interval of 95\%.

those with higher incomes, and also tended to get involved with risk behavior more frequently ${ }^{27}$.

Another association with unsatisfactory RP was found with the variable of not participating in a social group other than the HLP. A potential explanation is that those individuals with unsatisfactory RP less frequently attend extra-home activities. One study shows that participation in social groups may influence the RP of people; that is, an individual who is socially and culturally diverse is strongly influenced by more varied individual and emotional factors, as they have contact with more varied experiences and information transmitted in the milieu where they are inserted ${ }^{28}$. Taking part in social groups may lead individuals to either underestimate or overestimate the risks to which they are exposed.

This study's elderly individuals with unsatisfactory RP tend to remain at home, less regularly interact with their peers and health workers who organize groups or programs directed to this specific population. Therefore, they are less likely to obtain information that is relevant to their health through an exchange of experiences and observations with other elderly individuals and health workers.

The items assessed in the Fall Risk Score (history of falls, use of medications, sensorial deficit, cognitive and gait changes) may explain the association between low risk for falls and unsatisfactory RP. These individuals presented a history of few falls and this fact may influence RP. One study addressing elderly individuals with a low perception of risk for falls were less likely to fall because they had not fallen before ${ }^{29}$.

Additionally, we can infer that elderly individuals who do not use medications that contribute to the occurrence of falls, do not present sensorial deficits, or significant gait or cognitive problems, do not consider the risk factors present in their environments or their behaviors as being risky.

A similar result is reported by a study conducted with elderly individuals in Australia. The group presenting a low perception of risks did not consider themselves to be at risk of falling. These individuals had a more active lifestyle, presented a lower rate of falls, and used a smaller amount of psychotropic medications ${ }^{29}$.

\section{CONCLUSIONS}

A higher prevalence of satisfactory RP was found in this study and it may be considered a good result, as it increases the probability of these individuals adopting preventive measures. There is, however, a large portion of these elderly individuals who present unsatisfactory RP of risk factors for falls. This result is significantly associated with low income, not being part of a social group other than the HLP, and low risk for falls.

These findings contribute to knowledge of falls among elderly individuals and indicate the need for health workers, especially nurses, to assess the RP of elderly individuals regarding risk factors to which they are daily exposed to implement preventive measures.

Additionally, future studies are needed to investigate other aspects influencing the perception of risk factors for falls among elderly individuals using the technique of vignettes as an innovative methodological resource. This resource facilitates the collection of subjective data such as one's own and others' perceptions, which can favor proposing preventive strategies that are meaningful within the context experienced by these individuals, thus encouraging greater adherence on the part of these individuals to preventive measures.

To complement these findings, studies addressing the RP of risk factors for falls among groups of elderly individuals with different characteristics (e.g., 80 years old or older) are also suggested.

This study's limitation lies on the fact that the individuals addressed here belong to a specific group attending a program, which hinders the possibility of generalizations. The results, however, do reveal aspects concerning this population's risk perceptions that enable improved knowledge of what these individuals understand about falls. 


\section{FINANCIAL SUPPORT}

Project funded by the National Academic Cooperation Program - Procad/Capes, Public Notice № 071/2013.

\section{REFERENCES}

1. Organização Mundial de Saúde (OMS). World Health Organization - WHO Global report on falls prevention in older age. Translated by Secretaria de Estado da Saúde de São Paulo [Internet]. 2010; [cited 2015 Apr 1]; 1-64. Available from: http://www.saude.sp.gov.br/resources/ccd/ publicacoes/publicacoes-ccd/saude-e-populacao/manual_oms_-_site. pdf

2. Pimentel WRT, Pagotto V, Stopa SR, Hoffmann MCCL, Andrade FB, Souza Junior PRB, et al. Quedas entre idosos brasileiros residentes em áreas urbanas: ELSI-Brasil. Rev Saúde Pública [Internet]. 2018 Oct; [cited 2019 May 22]; 52(Supl 2):12s. Available from: http://www.scielo.br/ scielo.php?script $=$ sci arttext\&pid $=$ S0034-89102018000300508\& $\mathrm{In}$ $\mathrm{g}=e n \& n r m=i s o \&$ tlng=pt. DOI: https://doi.org/10.11606/S15188787.2018052000635

3. Di Giulio GM, Vasconcellos MP, Günther WMR, Ribeiro H, Assunção JV. Risk perception: a field of interest for the interface between environment, health, and sustainability. Saúde Soc (São Paulo) [Internet].2015 Dec; [cited 2019 May 28]; 24(4):1217-31. Available from: http://www.scielo. br/pdf/sausoc/v24n4/en_1984-0470-sausoc-24-04-01217.pdf. DOI: http://dx.doi.org/10.1590/S0104-12902015136010

4. Martins CL, Echevarría-Guanilo ME, Silveira DT, Gonzales RIC, Dal Pai D. Risk perception of work-related burn injuries from the workers perspective. Texto Contexto Enferm [Internet]. 2015 Oct/Dec; [cited 2016 Apr 3]; 24(4):1148-56. Available from: http://www.scielo.br/scielo. php?script=sci_arttext\&pid=S0104-07072015000401148\&lng=en\&tln $\mathrm{g}=$ en. DOI: $10.1590 / 0104-0707201500000880015$

5. Chippendale T, Boltz M. The Neighborhood Environment: Perceived Fall Risk, Resources, and Strategies for Fall Prevention. Gerontologist [Internet]. 2015 Aug; [cited 2015 Jun 26]; 55(4):575-83. Available from: https://www.ncbi.nlm.nih.gov/pubmed/24836115. DOI: 10.1093/ geront/gnu019

6. Abreu NJA, Zanella ME. Percepção de riscos de inundações: Estudo de caso no bairro Guabiraba, Maranguape - Ceará. Rev Okara Geog Deb [Internet]. 2015; [cited 2016 Apr 3]; 9(1):90-107. Available from: http://www.periodicos.ufpb.br/ojs2/index.php/okara/article/ view/23859/13408

7. Börner S, Albino JCT, Caraveo LMN, Tejeda ACC. Exploring Mexican adolescents' perceptions of environmental health risks: a photographic approach to risk analysis. Ciênc Saúde Coletiva [Internet]. 2015; [cited 2016 May 20]; 20(5):1617-27. Available from: http://www.scielo.br/ pdf/csc/v20n5/1413-8123-csc-20-05-01617.pdf. DOI: 10.1590/141381232015205.11382014

8. Borsanelli AC, Samara SI, Ferraudo AS, Dutra IS. Escolaridade e volume de produção têm associação com a percepção de risco de produtores de leite no uso de produtos veterinários. Pesq Vet Bras [Internet]. 2014 Oct; [cited 2016 May 13]; 34(10):981-9. Available from: http:// www.scielo.br/pdf/pvb/v34n10/10.pdf. DOI: http://dx.doi.org/10.1590/ S0100-736X2014001000010

9. Santos WJ, Giacomin KC, Firmo JOA. Avaliação da tecnologia das relações de cuidado nos serviços em saúde: percepção dos idosos inseridos na Estratégia Saúde da Família em Bambuí, Brasil. Ciênc Saúde Coletiva [Internet]. 2014; [cited 2016 Apr 10]; 19(8):3441-50. Available from: http://www.scielo.br/pdf/csc/v19n8/1413-8123-csc-19-08-03441.pdf. DOI: 10.1590/1413-81232014198.14172013

10. Barcenilla-Wong AL, Chen JS, March LM. Concern and risk perception of osteoporosis and fracture among post-menopausal Australian women: results from the Global Longitudinal Study of Osteoporosis in Women (GLOW) cohort. Arch Osteoporos [Internet]. 2013; [cited 2016 Apr 15]; 8:155. Available from: https://www.ncbi.nlm.nih.gov/pubmed/24105339. DOI: 10.1007/s11657-013-0155-y
11. Figueiredo LG, Silva RAR, Silva ITS, Souza KGS, Silva FFA. Percepção de mulheres casadas sobre o risco de Infecção pelo HIV e o comportamento preventivo. Rev Enferm UERJ [Internet]. 2013 Dec; [cited 2015 Oct 15]; 21(no.spe2):805-11. Available from: http://www. facenf.uerj.br/v21esp2/v21e2a18.pdf. DOI: 10.1186/s12905-0140152-3.

12. Kartal M, Ozcakar N, Hatipoglu S, Tan MN, Guldal AD. Breast cancer risk perceptions of Turkish women attending primary care: a cross-sectiona study. BMC Womens Health [Internet]. 2014 Dec; [cited 2015 Oct 15]; 14:152. Available from: https://www.ncbi.nlm.nih.gov/pmc/articles/ PMC4262994/

13. Braun B. Knowledge and perception of fall-related risk factors and fall-reduction techniques among community-dwelling elderly individuals. Phys Ther [Internet]. 1998; [cited 2015 Sep 9]; 78(12):1262-1276. Available from: https://academic.oup.com/ptj/ article-abstract/78/12/1262/2633231. DOI: https://doi.org/10.1093/ ptj/78.12.1262.

14. Garcia RR, Gelsi TA, Sabaté ACC. The perception of risk factors for falls in a group of elderly women. Rev Bras Ciênc Saúde [Internet]. 2007; [cited 2015 Sep 6]; 5(11):41-51. Available from: http://seer.uscs.edu. br/index.php/revista_ciencias_saude/article/view/415.DOI: 10.13037/ rbcs.vol5n11.415

15. Moura SRB, Vieira JPPN, Santos AMR, Mesquita GV, Ribeiro JLV. Perception of the elderly about the risk of falls. Rev Interdisciplin [Internet]. 2017 Oct - Dec; [cited 2018 Jul 1]; 10(4):1-13. Available from: https://revistainterdisciplinar.uninovafapi.edu.br/index.php/revinter/ article/view/1291

16. Morsch P, Myskiw M, Myskiw JC. Falls' problematization and risk factors identification through older adults' narrative. Ciênc Saúde Coletiva [Internet]. 2016; [cited 2017 Fev 8]; 21(11):3565-74. Available from: https://www.scielosp.org/article/csc/2016.v21n11/3565-3574/. DOI: 10.1590/1413-812320152111.06782016

17. Ministério da Saúde (BR). Envelhecimento e saúde da pessoa idosa. Min exame do estado mental (MEEM). (Anexo C). Secretaria de Atenção à Saúde. Departamento de Atenção Básica. Brasília (DF): Ministério da Saúde;2007 [Internet]. [citado 2015 Oct 18]. Available from: https:// app2.unasus.gov.br/UNASUSPlayer3/recursos/SE_UNASUS_0001_ SAUDE_PESSOA IDOSA/4/lib/docs/mini-exame-do-estado-mental. pdf

18. Evans SC, Roberts MC, Keeley JW, Blossom JB, Amaro CM, Garcia AM, et al. Vignette methodologies for studying clinicians decision-making: validity, utility, and application in ICD-11 fieldstudies. Int $\mathrm{J}$ Clin Health Psychol [Internet]. 2015 May/Aug; [cited 2019 May 27]; 15(2):160-70. Available from: https://reader.elsevier.com/reader/sd/pii/S1697260014 000660? token=6AAF8E8133CD46BC93D591F58596AAF8E16069C 7836433831A7507163F2D2A4957C32BC20B15481661EA88D018B CDF80. DOI: http://dx.doi.org/10.1016/j.jijchp.2014.12.001

19. Schiaveto FV. Avaliação do risco de quedas em idosos na comunidade [dissertação]. Ribeirão Preto (SP). Universidade de São Paulo. Escola de Enfermagem de Ribeirão Preto;2008 [cited 2018 May 15]. Available from: http://www.teses.usp.br/teses/disponiveis/22/22132/tde-19122008153736/pt-br.php. DOI: http://dx.doi.org/10.11606/D.22.2008.tde19122008-153736

20. Camargos FFO, Dias RC, Dias JM, Freire MTF. Cross-cultural adaptation and evaluation of the psychometric properties of the Falls Efficacy Scale - International Among Elderly Brazilians (FES-I-BRAZIL). Rev Bras Fisioter [Internet]. 2010; [cited 2018 Apr 22]; 14(3):237-43. Available from: http://www.scielo.br/pdf/rbfis/v14n3/en_10.pdf.DOl: http://dx.doi. org/10.1590/S1413-35552010000300010

21. Areosa J. Perceptions of occupational risks in the railway sector. Socio Probl Prát [Internet]. 2014 [cited 2016 Apr 2]; 75:83-107. Available from: http://www.scielo.mec.pt/scielo.php?script=sci_arttext\&pid=S0873$65292014000200004 \&$ Ing $=$ pt\&nrm=iso\&tlng=pt. DOI: $10.7458 /$ SPP2014753577

22. Areosa J. A importância das percepções de riscos dos trabalhadores. Int J Work Cond [Internet]. 2012; [cited 2016 Feb 1]; 3:54-64. Available from: http://ricot.com.pt/artigos/1/J.Guanais_pp.65.84.pdf 
23. Bartoszeck FK, Thielen IP. Conceitos precursores no entendimento da Percepção de Risco. J Ciênc Cogn [Internet]. 2011; [cited 2016 Apr 5];1:14-0. Available from: http://www.jcienciascognitivas.home. sapo.pt

24. Dollard J, Barton C, Newbury J, Turnbull D. Falls in old age: a threat to identity. J Clin Nurs [Internet]. 2012 Sep; [cited 2015 Oct 28] 21(17-18):2617-25. Available from: https://www.ncbi.nlm.nih.gov/ pubmed/22393883. DOI: 10.1111/j.1365-2702.2011.03990.x

25. Pagotto V, Bachion MM, Silveira EA. Self-evaluation of health by Brazilian elderly: a systematic review of the literature. Rev Panam Salud Publica [Internet]. 2013; [cited 2017 Jan 31]; 33(4):302-10. Available from: https://www.scielosp.org/scielo.php?pid=S102049892013000400010\&script=sci_arttext

26. Lipp MEN, Barbieri FE, Santánna L, Justo AP, Cabral AC, Santos FU, et al. Perception of risk of electric and magnetic fields: effects of stress and other psychological aspects. Estud Psicol (Campinas) [Internet]. 2013 Oct/Dec; [cited 2015 Oct 2]; 30(4):497-506. Available from: http://www.scielo.br/scielo.php?script=sci_arttext\&pid=S0103166X2013000400003. DOI: http://dx.doi.org/10.1590/S0103$166 \times 2013000400003$.
27. Vieira KM, Flores SAM, Potrichet ACG, Campara JP, Parabonial AL. Perception and behavior of financial risk: analysis of the influence of occupation and other sociodemographic variables. Rev Gest Finan Contab [Internet]. 2013; [cited 2016 Apr 6]; 3(3):130-47. Available from: https://www.researchgate.net/publication/285102979_Percepcao_e_ Comportamento_de_Risco_Financeiro_Analise_da_Influencia_ da_Ocupacao_e_Demais_Variaveis_Sociodemograficas. DOI 10.18028/2238-5320/rgfc.v3n3p130-147

28. Sampaio Filho FJL, Sousa PRM, Vieira NFC, Nóbrega MFB, Gubert FA, Pinheiro PNC. Perception of risk of school adolescents in relation to alcohol consumption and Sexual behavior. Rev Gaúcha Enferm [Internet]. 2010 Sep; [cited 2017 May 12]; 31(3):508-14. Available from: http://www.scielo.br/scielo.php?script=sci_arttext\&pid=S198314472010000300014\&lng=en\&nrm=iso. DOl: http://dx.doi.org/10.1590/ S1983-14472010000300014

29. Delbaere K, Close JCT, Brodaty H, Sachdev P, Lord SR. Determinants of disparities between perceived and physiological risk of falling among elderly people: cohort study. BMJ [Internet]. 2010; [cited $2015 \mathrm{Jul} 13$ ] 341:c4165. Available from: https://www.bmj.com/content/341/bmj. c4165. DOI: https://doi.org/10.1136/bmj.c4165 